\title{
Selectie voor de aanvang van de studie geneeskunde in Nederland en Vlaanderen
}

"Het onderwerp selectie komt met enige regelmaat terug op de onderwijsagenda's", schreef Scherpbier ruim twee jaar geleden in dit blad. Intussen zijn er enkele ontwikkelingen met betrekking tot de numerus fixus in Nederland en wordt het nu duidelijk wat het gevolg is van een ingezette trend in Vlaanderen. In Nederland en België (en waar niet in Europa?) koos men voor een gereguleerde instroom van studenten. In Vlaanderen gaat men sinds enkele jaren rigoureus te werk (tabel 1).

De inmiddels vervangen minister stelde onlangs in het federale Belgische parlement dat "ook met de contingentering (beperking van het aantal studenten), de medische werkkracht jaar na jaar blijft toenemen. Schakelt men het jaar 2000 gelijk aan $100 \%$, dan bedraagt die werkkracht bij de huisartsen in 2007 104\%. Daarna zit de klad er wat in. Maar zelfs in 2011 is er toch nog 2,9\% meer huisartsenwerkkracht dan in 2000. Bij de specialisten is de groei iets minder uitgesproken. In 2006 ligt de werkkracht 3,9\% hoger dan in 2000. In 2011 is dat nog 2,6\%." De vraag is of de minister gelijk heeft.

Laten we de situatie in de beide landstreken eens van nabij bekijken. De redenen voor een strenge numerus fixus vanaf de jaren zeventig in Nederland waren divers. Zo dacht men dat een teveel aan zorgverstrekkers aanleiding geeft tot hogere kosten voor de gezondheidszorg (economische en politieke motieven). Een teveel aan artsen zou ook leiden tot te weinig werk en minder inkomen voor de individuele artsen (argumenten die vooral in de medische beroepsgroepen speelden).

Men heeft echter niet op tijd ingezien dat de wereld er snel anders is gaan uitzien. Er is een aantal factoren waar de gehanteerde rekenmodellen niet in voorzien. Dit zijn onder andere de vervrouwelijking van het artsenberoep, met bijbehorende parttime arbeid en zelfs uittreding. Bij mannen is er ook een wens om parttime te werken en afwisselend en flexibel werk te hebben. ${ }^{4}$ Gezien de samenstelling van de leeftijd-

Tabel 1.

\begin{tabular}{lll}
\hline & Nederland & Vlaanderen \\
\hline Aantal inwoners & 16.000 .000 & 6.000 .000 \\
Aantal praktiserende medische & & \\
FTE/10.000 inwoners & $20.73^{1}$ & $26.73^{1}$ \\
Instroom studenten 1992 & $1485^{1}$ & $1144^{2}$ \\
Instroom studenten 1993 & $2010^{1}$ & $1185^{2}$ \\
Instroom studenten 2002 & $2400^{3^{*}}$ & $360^{2}$ \\
Wijze van selectie & Gemengd: loting en decentrale selectie & Ingangsproef \\
\hline
\end{tabular}

* In juni 2002 werd besloten dit aantal te verhogen naar 2550. 
piramide van artsen is er binnenkort een flinke vergrijzing te verwachten. Deze ontwikkelingen leiden tot een verminderde productiviteit van de opgeleide medische menskracht. ${ }^{1}$ Daarnaast zijn er ontwikkelingen in de geneeskunde die hebben gemaakt dat er meer menskracht nodig is. Denk aan het ontstaan van nieuwe disciplines (bijvoorbeeld verpleeghuisgeneeskunde, artsen voor gehandicapten, artsen voor urgentiegeneeskunde, fertiliteitsartsen en artsen voor het beheer van medische informatiesystemen). Ook de toenemende medicalisering van het dagelijks leven en dito bureaucratisering van de zorg leiden tot de noodzaak meer mankracht in te zetten.

Het gevolg, in Nederland tenminste, zijn tekorten in aantallen medici. Dit geeft mede aanleiding tot vervelende fenomenen zoals wachtlijsten in ziekenhuizen, en binnenkort zijn ook veel patiënten zonder huisarts. De oplossingen van deze problemen zijn niet voor morgen. De leiders van de artsenverenigingen en in hun kielzog de politici hebben onvoldoende ingezien welke demografische en socio-culturele veranderingen er plaats zouden vinden.

Hoe is het gesteld in België? Aan de Vlaamse universiteiten was tot voor kort geen sprake van enige instroombeperking. Dit betekende dat er veel studenten uiteindelijk een doktersdiploma haalden. Dit op zijn beurt leidde tot wat in Vlaamse artsenkringen de 'plethora' wordt genoemd.

Belangrijk om vast te stellen is dat dit proces in België niet geleid heeft tot een duurdere gezondheidszorg dan in de omliggende landen en minder tot ontevreden patiënten. Maar omwille van alarmerende gegevens met betrekking tot het overaanbod van artsen (op basis van een mengeling van economische motieven en druk van beroepsgroepen) is er vanaf 1997 ook sprake van een instroombeperking met als selectie-instrument een ingangstoets. Tevens werd vastgelegd hoeveel studenten in de curatieve sector tewerkgesteld kunnen worden.

In Vlaamse artsenkringen ontstaat er nu enige ongerustheid. Ook hier komen immers dezelfde veranderingen zoals we die in Nederland zien, op gang. In de wandelgangen van de faculteit en in gesprekken met collega's hoor ik vragen over hoe dit gaat uitpakken. Hoe gaan de specialisatieplaatsen opgevuld worden? Wie gaat het werk van de assistenten in opleiding doen? Zijn er nog wel genoeg jonge artsen die nog voor een huisartsopleiding willen kiezen? Vinden we nog wel een opvolger voor een afzwaaiende collega?

Men kan stellen dat beide landen uit fase zijn. Nederland kent een verruiming, Vlaanderen een vermindering van het aantal studenten. Maar Nederland heeft van de twee landen het grootste probleem. We weten dat voor het enigszins rechttrekken van de tekorten aan artsen er minimaal een periode van negen jaar (de opleidingstijd van een huisarts) moet verstrijken. Als de genoemde trends, dus een vermindering van de gemiddelde productiviteit van artsen, zich verder zetten, zal deze periode nog langer zijn. Pogingen om artsen uit andere landen van de Europese gemeenschap binnen te halen zijn nog niet erg succesvol. Er ontstaat dus een langdurige periode van schaarste van het product arts. In België is de situatie wat minder problematisch. Er zijn nog geen schrikbarende tekorten, maar toch zal men op tijd de voet van de rem moeten halen, wil men niet in hetzelfde vaarwater komen als Nederland.

Helaas bestaat er in beide landen geen duidelijk masterplan hoe de gezondheidszorg moet evolueren. Europese schaalvergroting en verdere liberalisering maken het inschatten van de toekomst nog moei- 
lijker. Dus op korte en middellange termijn zijn er veel onduidelijkheden. Een goede behoeftenschatting en het reguleren van het artsenaanbod is daarom een hachelijke onderneming.

Omdat in Nederland is gebleken dat de numerus fixus gefaald heeft als instrument om het artsenaantal te reguleren en omdat in elk rekenmodel zoveel factoren niet gewogen kunnen worden, pleit ik ervoor om zeer voorzichtig om te gaan met het instrument numerus fixus. In Vlaanderen moeten de ontwikkelingen van heel dichtbij gevolgd worden om proactief in te kunnen grijpen ruim voor het tekort aan menskracht zichtbaar wordt. De minister moet weten dat een grote tanker op kruissnelheid wel tien kilometer nodig heeft om tot stilstand te komen.

\section{Roy Remmen}

\section{Literatuur}

1. Anoniem. Rapport over de beperking van het medisch aanbod. http://www.health.fgov.be/AGP/nl/ manpower/planningscommissie/rapport_14juni. pdf. Brussel: Ministerie van Sociale Zaken, Volksgezondheid en Leefmilieu; 2000.

2. Anoniem. Generatiestudenten (eerste jaar). http://www.vlir.be/vlir/beheer/personeel/generatie.htm. Brussel, Interuniversitaire Raad (VLIR); 2002.

3. Anoniem. Opleidingen met numerus fixus voor het studiejaar 2002-2003. Utrecht: Vereniging van Samenwerkende Nederlandse Universiteiten; 2002. http://www.vsnv.nl/show?id=1153xlangid $=246$.

4. Leese B, Young R, Sibbald B. GP principals leaving practice in the UK. Similarities and differences between men and women at different career stages. The European Journal of General Practice 2002; 8: 62-8. 